\title{
SHORT-TERM EFFECTS OF PHOSPHATE FERTILIZER ENRICHED WITH LOW- MOLECULAR-WEIGHT ORGANIC ACIDS ON PHOSPHORUS RELEASE KINETICS AND ITS AVAILABILITY UNDER CALCAREOUS CONDITIONS IN ARID REGION
}

\author{
A. MIHOUB ${ }^{1,2^{*}}$, M. DADDI BOUHOUN ${ }^{2}$, A. NAEEM3 \\ ${ }^{1}$ Scientific and Technical Research Centre for Arid Areas, Touggourt, Algeria \\ ${ }^{2}$ Laboratory Ecosystem Protection in Arid and Semi-Arid Areas, University of Kasdi Merbah, Ouargla, Algeria \\ 3Soil and Environmental Sciences Division, Nuclear Institute for Agriculture and Biology, Faisalabad, Pakistan
}

\begin{abstract}
The objective of this work was to investigate the effect of some low-molecular-weight organic acids (LMWOAs) on phosphorus release and availability in calcareous soil. Experiments were conducted in laboratory. Soil-limestone mixtures were prepared to achieve highly calcareous samples (i.e. $50 \% \mathrm{CaCO}_{3}$ ). The prepared samples were mixed thoroughly with phosphate fertilizers i.e. Triple super phosphate (TSP) and Mono-ammonium Phosphate (MAP) and watered with distilled water only ( $\mathrm{C}_{\mathrm{K}}$ ), with citric acid solution $\left(\mathrm{C}_{\mathrm{A}}\right)$ and with oxalic acid solution $\left(\mathrm{O}_{\mathrm{A}}\right)$. The treatments were arranged in a $\mathrm{CRD}$ with three replications and incubated at $25 \pm 2{ }^{\circ} \mathrm{C}$ and $80 \%$ soil moisture for a period of $960 \mathrm{~h}$. The P release was modeled by parabolic equation to describe the decrease in $\mathrm{P}$ with time. As a result, all treatments showed a significant decrease in available $\mathrm{P}$ with time. Using LMWOAs showed important results and combination of phosphate fertilizers with both LMWOAs solutions exerted a very favorable effect on $\mathrm{P}$ availability in soil. The parabolic diffusion equation used was fitted well to experimental data. Addition of LMWOAs decreased loss in extractability of $\mathrm{P}$ with increasing soil available phosphorus fraction. Moreover, treatments irrigated by LMWOAs solutions released a lot of phosphorus compared to untreated treatments.
\end{abstract}

Keywords: Phosphorus release kinetic, Phosphorus availability, P fertilizers-LMWOAs combinations, Calcareous soil

\section{INTRODUCTION}

Phosphorus (P) is often an important nutrient for crop growth and production, but uptake from soil can be problematic because the majority of applied $\mathrm{P}$ is rapidly transformed into poorly available forms. $\mathrm{P}$ in the soil can easily be fixed or precipitated due to the low $\mathrm{P}$ use efficiency of most crops with only 10 25\% [1], and the high P fixation capacity of soils [2]. The plant availability of $\mathrm{P}$ in calcareous soils is usually restricted. Adsorption and precipitation reactionsare the predominant mechanisms which reduces $P$ availability for plants.

Currently, no site-specific fertilizer recommendations are available for Algerian soils. Consequently, it is urgent to make evolve the management of all agricultural practices including the fertilization to durable practices, integrating better the ecological processes, and supporting at the same time a high-quality production and the maintenance of soil productivity on the long term. Several studies have reported $\mathrm{P}$ sorption inhibition and its availability improvement attributed to competition for available binding sites competition and the formation of solution complexes by organic acids. Thus, the present research aims to investigate the effect of phosphate fertilizer combined with low-molecular-weight organic acids (LMWOAs) on phosphorus release kinetics and its availability in calcareous soil.

\section{MATERIALS AND METHODS}

\section{Soil sampling and physico-chemical characterisation of experimental soil}

Soil samples were collected from the surface layer (at $0-30 \mathrm{~cm}$ depth), belonging to a major soil types in Oued Righ (southern Algeria) as Psamment with loamy-sand textural class located at $33^{\circ} 29^{\prime} 47^{\prime \prime} \mathrm{N}, 5^{\circ} 39^{\prime} 39^{\prime \prime} \mathrm{E}$ in Oued Righ area. After air-drying, the soil is ground to pass a 2-mm sieve. After that, soil particle size distribution was determined by the pipette method and to determine soil class based on their

Received 26 December 2017; Accepted 10 February 2018

${ }^{*}$ Corresponding Author

A. Mihoub

Scientific and Technical Research Centre for Arid Areas, Touggourt, Algeria

Email: adilmihoub15@yahoo.com

( $T$ This article is open access and licensed under the terms of the Creative Commons Attribution License (http://creativecommons.org/licenses/by/4.o/) which permits unrestricted, use, distribution and reproduction in any medium, or format for any purpose, even commercially provided the work is properly cited. Attribution - You must give appropriate credit, provide a link to the license, and indicate if changes were made. 
physical texture, the international soil science society system (ISSS) was used. Soil pH, lime content, organic matter, and available phosphorus were determined.

\section{Development of $\mathrm{CaCO}_{3}$ amended soil}

One kg of each soil was taken in plastic buckets, and a level of $\mathrm{CaCO}_{3} 50 \%$ were developed, and air dried soil was mixed thoroughly with limestone. The soil was wetted with distilled water to attain field capacity and equilibrated at room temperature. After that, amended soil sample air dried, mixed, homogenized, passed through $2 \mathrm{~mm}$ sieve and stored for use in adsorption isotherm.

\section{Phosphorus adsorption isotherm}

Phosphorus adsorption isotherms were constructed using a series of solutions with $\mathrm{P}$ concentrations (o, 10, 20, 30, 50, and $100 \mu \mathrm{g} \mathrm{ml}^{-1}$ ) prepared from $\mathrm{KH}_{2} \mathrm{PO}_{4}$ in $0.01 \mathrm{M} \mathrm{CaCl}_{2}$. To $4 \mathrm{~g}$ soil sample, $50 \mathrm{ml}$ of the above-mentioned $\mathrm{P}$ solutions was added and three to four drops of toluene were added to prevent microbial activity. After that, the tubes were incubated at $25{ }^{\circ} \mathrm{C}$ for one week with $2 \mathrm{~h}$ shaking every day on a reciprocating shaker. After incubation period, the tubes were centrifuged at $4000 \mathrm{rpm}$ for $10 \mathrm{~min}$ and filtered. The $\mathrm{P}$ content in the supernatant solution was measured spectrophotometrically using Jenway 6310 spectrophotometer at a wavelength of $800 \mathrm{~nm}$ by the colorimetric molybdate-ascorbic acid method [3].

\section{Development of soil-limestone-phosphate fertilizer treatments}

The literature suggests that $\mathrm{EPR}_{0.2}$ adequately provides $\mathrm{P}$ for the normal growth of most of the crops if it is continuously maintained in the medium [4]. For computing $\mathrm{P}$ fertilizer quantities to achieve a desired soil solution $\mathrm{P}$ level, that is, $0.2 \mathrm{mg} \mathrm{L} \mathrm{L}^{-1}\left(\mathrm{EPR}_{0.2}\right)$, the linear version of Freundlich model was used (fig. 1). The prepared soil-limestone mixtures were mixed thoroughly either with phosphate fertilizers: $\mathrm{MAP}\left(52 \% \mathrm{P}_{2} \mathrm{O}_{5}\right)$ and TSP $\left(46 \% \mathrm{P}_{2} \mathrm{O}_{5}\right)$ and the amounts of added fertilizers for different treatments to be added were estimated by calculation (table 1).

\section{Preparation of LMWOAs solutions for irrigation}

Three irrigation solutions were prepared for use during our incubation study, namely:

- Distilled water $\left(D_{\mathrm{w}}\right.$ or $\left.\mathrm{C}_{\mathrm{K}}\right)$ : as a control, without LMWOAs input.

- Citric acid solution $\left(\mathrm{C}_{\mathrm{A}}\right)$ : A solution of $0.01 \mathrm{M}$ was prepared. This solution was characterized by: $\mathrm{pH}=4.7$ and $\mathrm{EC}=10.09 \mathrm{dS} \mathrm{m}^{-1}$.

- Oxalic acid solution $\left(\mathrm{O}_{\mathrm{A}}\right)$ : A solution of $0.01 \mathrm{M}$ was prepared. This solution was characterized by: $\mathrm{pH}=2.24$ and $\mathrm{EC}=3.38 \mathrm{dS} \mathrm{m}^{-1}$.

\section{Experimental design and used treatments}

Fifty grams (50 g) of each soil sample was taken into plastic pots in triplicate. To the each soil sample, $15 \mathrm{ml}$ of $0.01 \mathrm{M}$ citric or oxalic acid solution were added. The samples with $15 \mathrm{ml}$ of distilled water served as control. Overall, this constituted following three treatments: (i) control, distilled water only $\left(\mathrm{D}_{\mathrm{w}}\right)$, (ii) soils treated with citric acid $\left(\mathrm{C}_{\mathrm{A}}\right)$ and (iii) soils treated with oxalic acid $\left(\mathrm{O}_{\mathrm{A}}\right)$. The treatments were arranged in a CRD with three replications and incubated at a temperature of $25 \pm 2{ }^{\circ} \mathrm{C}$ and $80 \%$ soil moisture (v/w) for a period of $960 \mathrm{~h}$. At the end of each incubation period of $240 \mathrm{oh}, 54$ pots were eliminated and the soil samples in the eliminated pots were air-dried and ground to pass through a 2-mm sieve prior to analyses. Afterwards, soluble $\mathrm{P}$ was determined in $0.01 \mathrm{M}$ of $\mathrm{KCl}$ extract (soil-solution ratio of 1:10) as described by Black (1965). For Olsen-P, soil samples were extracted with $0.5 \mathrm{M} \mathrm{NaHCO}_{3}$ (soil-solution ratio of 1:20) for $30 \mathrm{~min}$ of shaking and concentration was measured using ascorbic acid method as described by Murphy and Riley [3].

\section{Data processing}

The amount of $\mathrm{P}$ adsorbed (Q) was calculated from the difference between $\mathrm{P}$ added and the equilibrium $\mathrm{P}$ concentration (C).

$$
\mathrm{Q}=\frac{\mathrm{V} \Delta \mathrm{C}}{\mathrm{M}}[1]
$$

Where: $\mathrm{Q}$ is amount of $\mathrm{P}$ adsorbed $\left(\mu \mathrm{g} \mathrm{g}^{-1}\right), \Delta \mathrm{C}$ is difference between initial and final (equilibrium) phosphate concentrations in the supernatant solution (mg $\mathrm{P} \mathrm{L}^{-1}$ ), $\mathrm{V}$ is the volume of solution $40 \mathrm{ml}$ and $\mathrm{M}$ is mass of soil (4 g). The measurement was run in four determinations, means of which wereused for further calculations. The data obtained from the phosphate adsorption experiment were fitted to the general form of Freundlich equation as follows:

$$
X=a C n[2]
$$

Where: $\mathrm{X}$ is amount of $\mathrm{P}$ sorbed per gram of soil ( $\mu \mathrm{g} \mathrm{P} \mathrm{g}^{-1}$ soil), $\mathrm{C}$ is concentration of $\mathrm{P}$ in equilibrium solution (mg $\mathrm{L}^{-}$ $\left.{ }^{1}\right),(a)$ is a constant related to sorption capacity $\left(\mu \mathrm{g} \mathrm{g}^{-1}\right)$, and $n$ is phosphate sorption energy $\left(\mathrm{mL} \mathrm{g}^{-1}\right)$.

The logarithmic relationship between $\mathrm{C}$ and $\mathrm{P}$ absorbed per unit weight of the soil (X) from which the parameters $a$ and $n$ were calculated.

$$
\log X=\log a+(n \times \log C)[3]
$$

Where: $(a)$ is a constant related to sorption capacity ( $\mu \mathrm{g} \mathrm{g}$ ${ }^{1}$ ), and $n$ is phosphate sorption energy $\left(\mathrm{mL} \mathrm{g}^{-1}\right)$. EPR is the external phosphate requirements and it was calculated by the following equation:

$$
\mathrm{EPR}=10 \log \mathrm{X}[4]
$$

Parallel to the adsorption isotherm study, the parameters of parabolic diffusion model were used to describe $\mathrm{P}$ transformation rates and its decrease with time in control and treated soil with LMWOAs. The parabolic diffusion equation which was employed for the fitting of the experimental results is:

$$
\mathrm{Qt}=\mathrm{Qe}+\mathrm{Rt} 1 / 2[5]
$$

Where: $Q_{t}$ is the $\mathrm{P}$ decreased within time $t ; Q_{e}$ and $R$ are constants.

Statistical data analysis of processing differences was performed with the one-way ANOVA method of Statistica 10.0, showing a significance level below $5 \%$.

\section{RESULTS AND DISCUSSION}

\section{Experimental soil physico-chemical properties}

The soil was non-saline with a slightly alkaline $\mathrm{pH}$. The equivalent calcium carbonate content was $4 \mathrm{~g} \mathrm{~kg}^{-1}$. The Olsen-P value was $1.48 \mathrm{mg} \mathrm{kg}$ indicate that the experimental soil is very poor in phosphorus (table 2). 


\section{Effects of LMWOAs on $P$ availability}

All treatments showed a significant decrease in available $\mathrm{P}$ with time (Fig.2). This implies that as the incubation time is extended, the available phosphorus content decreases. The declining kinetics of phosphorus availability for the three treatments is mainly due to the transfer of phosphorus to non-extractable forms. [5] Found that after $2400 \mathrm{~h}, 45 \sim 80 \%$ of the Olsen-P was no longer extractable. In addition, [6] in benchmark soils from the semi-arid part of northeast Brazil. They applied $400 \mathrm{mg}$ of $\mathrm{P} \mathrm{kg}^{-1}$ of soil and found that the Olsen-P decreased progressively over $960 \sim 1200 \mathrm{~h}$. Using organic acids showed important results and combination of phosphate fertilizers with both organic acids (citric acid and oxalic acid) exerted a very favorable effect on $\mathrm{P}$ availability in soil. The use of organic substances (e. g. organic acids. etc.) is one of the solutions that can improve phosphorus availability in high P-fixing soils like calcareous soils. Several researches have shown that organic supplements can increase the available organic fraction of phosphorus in soils where Pfixing power is high [7]. Addition of low-weight organic acids may contribute to the activation of $\mathrm{Ca}-\mathrm{P}$ fractions that are blocked in limestone-rich soils [8].

\section{Kinetic fitting of phosphorus release}

The parabolic model was used for describing the decrease in $\mathrm{P}$ with time. Comparing the values of $r$ obtained, our experimental data were well fitted to the parabolic diffusion equation (table 3 ). The fit of the data to parabolic equation with is shown in fig. 3. The fit of the data to parabolic equation with is shown in fig. 3. A successful description of $\mathrm{P}$ kinetics by the parabolic equation model was reported on some limestone soils of Iran $[9,10]$. The slope (R) which represents the relative diffusion coefficient of phosphorus and it extractability loss over time and the negative value of $\mathrm{R}$ can be used as an index of transformation rates in a given soil. The values of this coefficient are variable in all treatments. The difference between $R$ values indicated that transformation power of the treatments in control and treated soils with LMWOAs was different. The constant $\mathrm{R}$ for $\mathrm{P}$ ranged from -0.750 to -0.986 in treatments without limestone amendments, and between -0.249 to $-0.809 \mathrm{mg} \mathrm{kg}^{-1} \mathrm{~h}^{-1 / 2}$ in soil with $50 \%$ of lime content. Generally the transformation rate of $\mathrm{P}$ was much higher in untreated soil than in other treated soils with LMWOAs. Addition of organic acids decreased $\mathrm{R}$ values with increasing soil available phosphorus fraction. These results show that $\mathrm{P}$ transformation indices decreased with improving phosphorus availability in soil causing an increase in the number of adsorption sites for this element. The same remarks were noted by [11] of which they found that the indices of phosphorus transformations increased with increasing phosphate inputs. Adding LMWOAs could improve the coefficient of diffusion of phosphorus in soil [12]. The parabolic diffusion equation showed that organic acids can improve the rate of phosphorus migration in soil [13]. As a result, a low concentration of LMWOAs in soils can decrease the phosphorus concentration and therefore the rate of diffusion of $\mathrm{P}$ will decrease. For the second parameter "Qe" (release amount of phosphorus, $\mathrm{mg} \mathrm{P} \mathrm{kg}^{-1}$ ). The lowest values were recorded in the treatments with no LMWOAs addition. However, treatments irrigated by organic acids solutions released a lot of phosphorus compared to others. Our results join those obtained by [13] that indicated that Qe values increased significantly with the application of organic acids.

Table 1: Applied fertilizers for different treatments

\begin{tabular}{llll}
\hline Treatments & EPR & Applied fertilizers $\left(\mathbf{g ~ k g}^{-1} \mathbf{~ s o i l}\right)$ & TSP \\
\cline { 2 - 4 } & & MAP & 0.000 \\
To & 00.00 & 0.000 & 0.526 \\
T1 & 105.81 & 0.466 & 0.46 \\
\hline
\end{tabular}

To: Unfertilized treatment; T1: Fertilized and calcareous amended treatment. The EPR is defined as the concentration of P in solution known to be non-limiting to plant growth. The doses were calculated from the adsorption isotherms (Freundlich model).

Table 2: Some physical and chemical properties of the studied soil

\begin{tabular}{ll}
\hline Parameters & Value \\
\hline Sand $\left(\mathrm{mg} \mathrm{kg}^{-1}\right)$ & 81.32 \\
Silt $\left(\mathrm{mg} \mathrm{kg}^{-1}\right)$ & 13.25 \\
Clay $\left(\mathrm{mg} \mathrm{kg}^{-1}\right)$ & 5.43 \\
Texture & Loamy sand \\
pH & 7.8 \\
Lime content $\left(\mathrm{mg} \mathrm{kg}^{-1}\right)$ & 4 \\
Organic carbon $(\%)$ & 0.5 \\
Available P $\left(\mathrm{mg} \mathrm{kg}^{-1}\right)$ & 1.48 \\
Soluble P $\left(\mathrm{mg} \mathrm{L}^{-1}\right)$ & 0.10 \\
\hline
\end{tabular}

Table 3: Parameters of parabolic diffusion model used to describe release of phosphorus in control and treated soil with LMWOAs

\begin{tabular}{|c|c|c|c|c|}
\hline \multirow[t]{2}{*}{$\mathrm{CaCO}_{3}$ level (\%) } & & \multicolumn{3}{|c|}{ Kinetic parameters } \\
\hline & & $\mathbf{R}$ & $Q_{e}$ & $\boldsymbol{r}$ \\
\hline \multirow[t]{3}{*}{ Native } & $\mathrm{D}_{\mathrm{w}}$ & -0.750 & 29.08 & 0.61 \\
\hline & $\mathrm{C}_{\mathrm{A}}$ & -0.909 & 33.27 & 0.66 \\
\hline & $\mathrm{O}_{\mathrm{A}}$ & -0.986 & 35.66 & 0.76 \\
\hline \multirow[t]{3}{*}{$50 \%$} & $\mathrm{D}_{\mathrm{w}}$ & -0.249 & 12.89 & 0.49 \\
\hline & $\mathrm{C}_{\mathrm{A}}$ & -0.753 & 31.29 & 0.37 \\
\hline & $\mathrm{O}_{\mathrm{A}}$ & -0.809 & 33.86 & 0.36 \\
\hline
\end{tabular}

$\mathrm{R}$ : loss in extractability of $\mathrm{P}$ in $\mathrm{mg} \mathrm{kg}^{-1} \mathrm{~h}^{-1 / 2} ; Q_{e}$ : release amount of phosphorus in $\mathrm{mg} \mathrm{P} \mathrm{kg}^{-1}$. 
A. Mihoub et al.

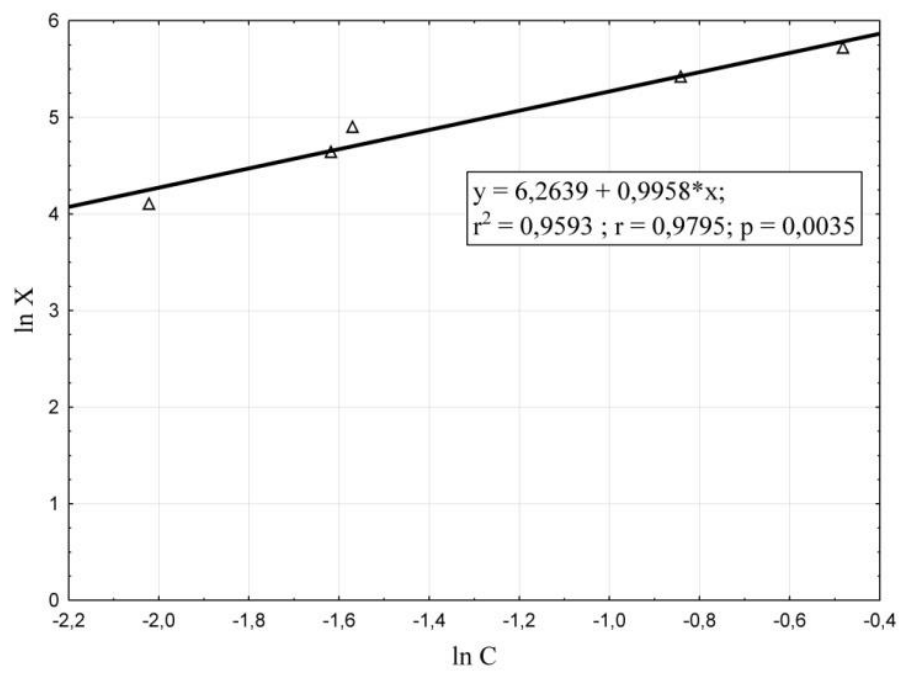

Fig. 1: Freundlich isotherm for $P$ adsorption
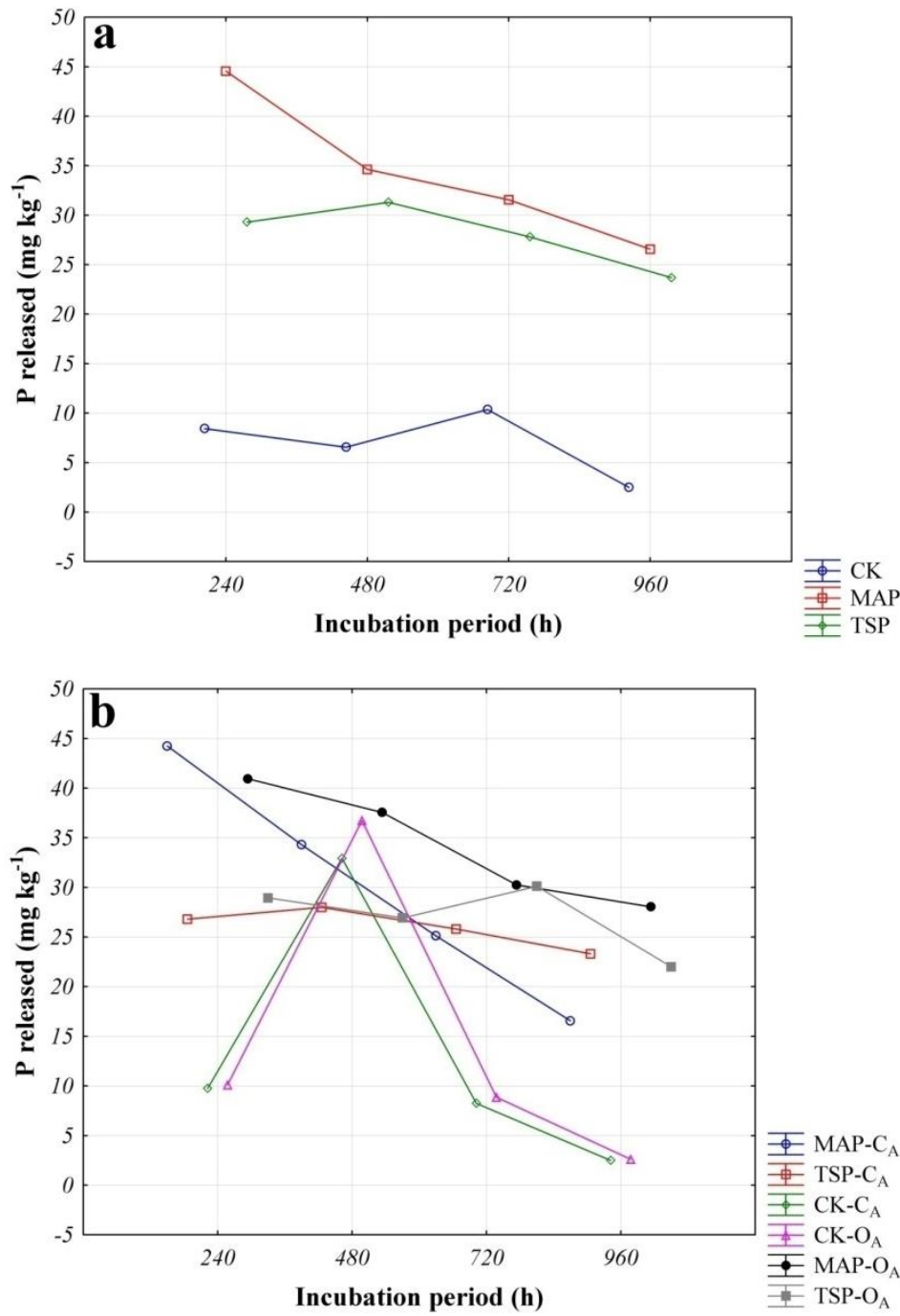

Fig. 2: Relationship between olsen-P released and time during incubation in (a) untreated soil and (b) treated soil with LMWOAs 


\section{CONCLUSION}

Actually, there is urgent need to increase P fertilizers use efficiency in different soil type such as calcareous soils. The kinetics of phosphate fertilizers contribute to the enrichment of the soil in available phosphorus, but the low solubility of phosphorus in the soil is partly due to its slow action in the limestone which must be certainly taken in the calculating the fertilizer doses to be made and for maintaining the phosphorus content of the soils at an acceptable level. Results arising from this work are that strategies for improving the efficiency of use of soil and fertilizer $\mathrm{P}$ are now available and the integration of inorganic $\mathrm{P}$ with low molecular weight organic acids could be considered as an effective and new $P$ fertilizer management approach for calcareous soil through lowering its adsorption in the soil.

\section{ACKNOWLEDGEMENT}

The authors are very grateful to the Scientific and Technical Research Center for Arid Areas (CRSTRA) for providing laboratory and other facilities for the implementation of this study.

\section{REFERENCES}

1. Xu G, Shao H B, Sun J N, Chang S X. Phosphorus fractions and profile distribution in newly formed wetland soils along a salinity gradient in the Yellow River Delta in China. J Plant Nutr. Soil Sci 2012;175:721-728.

2. Chakraborty D, Nair V D, Chrysostome M, Harris, W G. Soil phosphorus storage capacity in manureimpacted Alaquods: implications for water table management. Agric Ecosyst Environ 2011;142:167-175.

3. Murphy J, Riley J P. A modified single solution method for the determination of phosphate in natural waters. Anal Chim Acta 1962;27:31-36.
4. Nziguheba G, Palm C A, Buresh R J, Smithson P C. Soil phosphorus fractions and adsorption as affected by organic and inorganic sources. Plant Soil 1998;198:159-168.

5. Javid S, Rowell D L. A laboratory study of the effect of time and temperature on the decline in Olsen $\mathrm{P}$ following phosphate addition to calcareous soils. Soil Use Manage 2002;18:127-134.

6. Agbenin J O, Tiessen H. Phosphorus sorption at field capacity and soil ionic strength: kinetics and transformation. Soil Sci Soc Am J 1995;59:998-1005.

7. Gichangi E M, Mnkeni P N S. Effects of goat manure and lime addition on phosphatesorption by two soils from the Transkei Region, South Africa. Commun Soil Sci Plant Anal 2009;40:3335-3347.

8. Zhang A, He L, Zhao H, Wu Z. Effect of organic acids on inorganic phosphorus transformation in soil with different phosphorus sources. Chin J. Appl Environ Biol 2009;15:474-478.

9. Shariatmadari H, Shirvani M, Jafari A. Phosphorus release kinetics and availability in calcareous soils of selected arid and semi-arid toposequences. Geoderma 2006;132:261-272.

10. Jalai M, Ranjbar F. Aging effects on phosphorus transformation rate and fractionation in some calcareous soils. Geoderma 2010;155:101-106.

11. Mehrizi Hejazi M, Sarcheshmeh M, Ebrahimi Z. The effects of some humic substances and vermicompost on phosphorus transformation rate and forms in a calcareous soil. J Soil Sci Plant Nutr 2015;15:249-260.

12. Feng C. The research on the mechanism and effects of organic acids on soil p release in continuous leaching conditions. Shenyang Agricultural University. 2012.

13. Lv Y C, Xu G, Sun J N, Brestič M, Živčák, M, et al. Phosphorus release from the soils in the Yellow River Delta: dynamic factors and implications for ecorestoration. Plant Soil Environ 2015;61:339-343. 